\title{
PENGARUH MEDIA PEMBELAJARAN VIDEO TERHADAP MOTIVASI BELAJAR DAN SPEAKING SKILLS SISWA DI SMA NEGERI 02 KOTA JAMBI
}

\author{
SITI AISYAH \\ SMA Negeri 02 Kota Jambi, Provinsi Jambi \\ Email : aisyahheru72@gmail.com
}

\begin{abstract}
ABSTRAK
Penelitian ini bertujuan untuk menguji pengaruh media pembelajaran video terhadap motivasi dan keterampilan berbicara (speaking skills) siswa kelas XI pada mata pelajaran bahasa Inggris di SMA Negeri 2 Kota Jambi. Populasi penelitian ini adalah siswa SMA Negeri 2 Kota Jambi Provinsi Jambi. Sampel penelitian yang diambil yakni 125 siswa dari kelas XI IPA dan IPS. Data penelitian ini untuk mengetahui: (1) pengaruh media pembelajaran video terhadap motivasi belajar siswa, dan (2) pengaruhnya terhadap pembelajaran keterampilan berbicara (speaking skills) siswa kelas XI semester II. Teknik pengumpulan data yang digunakan adalah tes keterampilan berbicara bahasa inggris (speaking skills). (1) Berdasarkan hasil analisis, menunjukkan bahwa terdapat pengaruh yang signifikan media pembelajaran video terhadap motivasi belajar siswa (f hitung 5,050 dan $\mathrm{p}<0,050$ ). (2) Berdasarkan perhitungan statistik uji hipotesis dengan nilai $\mathrm{t}=54,077$ dengan Sig. 0,000< 0,05 Hi diterima artinya terdapat pengaruh media pembelajaran video terhadap keterampilan bicara (speaking skills) siswa kelas XI SMA Negeri 2 Kota Jambi. Kesimpulan dari penelitian ini adalah terdapat pengaruh media pembelajaran video terhadap motivasi belajar dan keterampilan bicara (speaking skills) siswa kelas XI SMA Negeri 2 Kota Jambi.
\end{abstract}

Kata Kunci: media pembelajaran video, motivasi belajar, speaking skills.

\section{PENDAHULUAN}

Bahasa merupakan alat utama dalam komunikasi. Bahasa yang baik dan benar memiliki efek penting dalam penentu perkembangan aspek kemajuan peradaban manusia. Tidak terkecuali aspek sosial, emosional bahkan intelektual siswa merupakan sisi perkembangan yang akan terus berubah dan berkembang. Pembelajaran bahasa diharapkan menjadi langkah strategis siswa untuk lebih mengenal dirinya, budayanya, dan budaya orang lain di sekitarnya. Selain itu, pembelajaran bahasa juga membantu siswa mampu mengekspresikan dan mengutarakan gagasan, ide dan perasaan, berpartisipasi dalam masyarakat, dan bahkan menemukan serta menggunakan kemampuan analitis dan imaginatif yang ada dalam dirinya.

Adapun Bahasa Inggris merupakan salah satu alat untuk berkomunikasi secara lisan dan tulisan. Berkomunikasi adalah memahami dan mengungkapkan informasi, pikiran, perasaan, dan mengembangkan ilmu pengetahuan, teknologi, dan budaya. Kemampuan berkomunikasi dalam pengertian yang utuh adalah kemampuan berwacana, yakni kemampuan memahami dan/atau menghasilkan teks lisan dan/atau tulis yang direalisasikan dalam empat keterampilan berbahasa, yaitu mendengarkan, berbicara, membaca dan menulis. Keempat keterampilan inilah yang digunakan untuk menanggapi atau menciptakan wacana dalam kehidupan bermasyarakat. Oleh karena itu, mata pelajaran Bahasa Inggris diarahkan untuk mengembangkan keterampilan- keterampilan tersebut agar lulusan mampu berkomunikasi dan berwacana dalam bahasa Inggris pada tingkat literasi tertentu.

Pembelajaran bahasa Inggris di SMP/MTs ditargetkan agar siswa dapat mencapai tingkat functional yakni berkomunikasi secara lisan dan tulis untuk menyelesaikan masalah sehari-hari, sedangkan untuk SMA/MA diharapkan dapat mencapai tingkat informational karena mereka disiapkan untuk melanjutkan pendidikannya ke perguruan tinggi. Tingkat literasi epistemic dianggap terlalu tinggi untuk dapat dicapai oleh siswa SMA/MA karena bahasa Inggris di Indonesia berfungsi sebagai bahasa asing. 
Sesuai dengan Kurikulum 2013 Mata Pelajaran Bahasa Inggris di SMA/MA bertujuan agar siswa memiliki kemampuan sebagai berikut: (1) Mengembangkan kompetensi berkomunikasi dalam bentuk lisan dan tulis untuk mencapai tingkat literasi informational. (2) Memiliki kesadaran tentang hakikat dan pentingnya bahasa Inggris untuk meningkatkan daya saing bangsa dalam masyarakat global. (3) Mengembangkan pemahaman siswa tentang keterkaitan antara bahasa dengan budaya. Keterampilan berbicara yang dilakoni pembelajar membutuhkan step-step khusus yang harus dilalui dengan berbagai pola, aturan dan bahkan tata krama saat berbicara sehingga terasa bagi siswa bahwa melakukan berbicara bahasa asing adalah sulit apalagi proses pembelajaran keterampilan itu tanpa dibantu dengan alat bantu pelajaran sehingga menambah sulit untuk diajarkan.

Beberapa fenomena tentang keterbatasan kemampuan warga belajar terhadap kemampuan berbicara menggunakan Bahasa inggris (speaking skills) baik di tingkat sekolah maupun tingkat perguruan tinggi masih terjadi. Bahkan, yang lebih ekstrem lagi adalah adanya guru mata pelajaran bahasa Inggris sendiri yang tidak bisa berbicara bahasa Inggris di depan siswanya atau sesama guru bahasa Inggris. Fenomena ini adalah sebuah kemungkinan yang terjadi sehingga banyak jumlah siswa yang enggan berbicara bahasa Inggris baik dengan rekan sekelas maupun di luar itu. Hal tersebut khususnya terbukti dari hasil data di SMA Negeri 2 Kota Jambi ditemukan fakta bahwa hampir $85 \%$ siswa masih belum terampil dalam berbicara ke dalam Bahasa inggris dengan baik dan benar (speaking skills). Maka oleh karena itu, perlu adanya pendekatan dan/atau baik metode dan media yang baru dalam proses pembelajaran Bahasa inggris di kelas.

Memang benar bahwa guru sebagai fasilitator yang baik untuk menyampaikan pesanpesan yang baik terhadap siswa. Kepandaian siswa tidak pernah terlepas dari teaching learning model of teacher (Gordon, 2000) karena guru yang baik adalah mampu mengubah sikap dan perilaku siswa dari yang belum bisa menjadi dapat berbuat, dari yang tidak tahu menjadi menguasai. Di satu sisi, guru juga dituntut untuk lebih kreatif dalam menyampaikan materi pembelajaran di kelas. Pemanfaatan media dalam pembelajaran akan memberikan andil dan daya pemahaman yang jauh lebih mudah dan komplit kepada siswa. Pemakaian media pembelajaran dalam proses belajar mengajar dapat membangkitkan minat dan keinginan yang baru, membangkitkan motivasi dan rangsangan kegiatan belajar, dan bahkan membawa pengaruh-pengaruh psikologis terhadap pebelajar. Penggunaan media pembelajaran pada tahap orientasi pengajaran akan sangat membantu keefektifan proses pembelajaran dan penyampaian pesan dan isi pelajaran pada saat itu. (Falahudin, 2014:104117).

Sebagai salah satu komponen pembelajaran, media tidak bisa luput dari pembahasan sistem pembelajaran secara menyeluruh. Pemanfaatan media seharusnya merupakan bagian yang harus mendapat perhatian pembelajar dalam setiap kegiatan pembelajaran. Namun kenyataanya bagian inilah yang masih sering terabaikan dengan berbagai alasan. Alasan yang sering muncul antara lain: terbatasnya waktu untuk membuat persiapan mengajar, sulitnya mencari media yang tepat, tidak tersedianya biaya, dan lain sebagainya. Hal ini sebenarnya tidak perlu terjadi jika setiap pembelajar telah membekali diri dengan pengetahuan dan keterampilan dalam hal media pembelajaran. Sesungguhnya betapa banyak jenis media yang bisa dipilih, dikembangkan dan dimanfaatkan sesuai dengan kondisi, waktu, biaya maupun tujuan pembelajaran yang dikehendaki. Setiap jenis media memiliki karakteristik tertentu yang perlu kita pahami, sehingga kita dapat memilih media yang sesuai dengan kebutuhan dan kondisi yang ada di lapangan. Salah satu media pembelajaran yang tepat untuk pembelajaran adalah media pembelajaran berbasis audiovisual yakni video.

Penggunaan media pembelajaran yang tepat dapat meningkatkan motivasi belajar siswa. Menurut Latuheru (2014:37), "Siswa akan mudah mengikuti pembelajaran jika pembelajaran berada dalam suasana yang menyenangkan". Dengan adanya pembelajaran yang menyenangkan dan bebas dari tekanan, siswa akan lebih mudah memahami materi pelajaran yang disampaikan oleh guru. Salah satu media yang dapat digunakan dalam proses 


\section{STRATEGY : Jurnal Inovasi Strategi dan Model Pembelajaran Vol 1. No 1. Juli Tahun 2021 e-ISSN : 2798-5466 P-ISSN : 2798-5725}

pembelajaran salah satunya adalah media video. Video merupakan salah satu jenis media pembelajaran yang berbasis audiovisual yang merangsang berfungsinya indera pendengaran dan indera penglihatan. Daryanto (2015:88) menyatakan bahwa, "Media video dapat dimanfaatkan dalam program pembelajaran karena dapat memberikan pengalaman yang tidak terduga kepada siswa".

Sebelum peneliti melakukan kegiatan observasi, selama ini proses pembelajaran dilakukan hanya berupa manual tanpa menggunakan media tambahan berupa media pembelajaran video (audiovisual). Sebagian besar materi bahasa Inggris disampaikan secara monoton dengan berbantuan buku ajar saja, sementara siswa hanya mendengar dan menulis. Fenomena inilah yang menyebabkan rendahnya motivasi keterampilan berbicara bahasa Inggris sehingga kebanyakan diantara siswa SMA Negeri 2 Kota Jambi hanya 3 orang saja yang bisa berbicara bahasa Inggris diantara 125 siswa.

Keengganan siswa untuk meningkatkan motivasi berbahasa Inggris bisa menjadi tolak ukur kelemahan seorang guru yang tidak memperkaya diri dengan berbagai fasilitas yang ada (Anshar: 2007). Sedangkan motivasi merupakan suatu perubahan energy dalam diri seseorang yang ditandai oleh munculnya perasaan dan reaksi untuk mencapai tujuan. (Fatmawati, 2017: 9-17).

Kegiatan guru dalam mengajarkan materi bahasa Inggris tidak harus terikat dan fokus dengan sistem konvensional yang hanya memberi muatan kognitif saja. Misalkan guru menugaskan siswa dengan ribuan kosa kata lalu menghafal beberapa tenses yang ada dalam grammar bahasa Inggris sehingga membuat siswa monoton, tidak ditampilkan dengan mediamedia untuk membangkitkan motivasi belajar, padahal tuntutan dari kurikulum bahasa Inggris adalah mengajak siswa aktif dalam melakukan dan menyelesaikan permasalahan yang ada dalam setiap pelajaran khususnya pelajaran bahasa Inggris.

Berdasarkan fakta hasil observasi di SMA Negeri 2 Kota Jambi, bahwa beberapa fasilitas yang ada sudah cukup untuk menerapkan metode dan media pembelajaran berbasis audiovisual (video). Antara lain ketersediaan LCD proyektor, unit komputer yang memadai dengan jumlah siswa, dan sebagian siswa telah memiliki unit laptop pribadi. Hal ini menjadi keuntungan dalam menerapkan media pembelajaran berbasis audiovisual (video). Namun di satu sisi, pemanfaatan media pembelajaran berbasis audiovisual (video) masih sangat jarang dilakukan. Hal tersebut menjadi dasar yang kuat untuk dilakukannya penelitian yang bertujuan untuk mengetahui sejauh mana keefektifan media pembelajaran video dalam proses belajar mengajar.

Selain itu pula, pelaksanaan proses belajar mengajar tidak saja didukung oleh strategi dan pendekatan (approach) pembelajaran yang bervariasi disesuaikan dengan karakteristik siswa, namun juga perlu memanfaatkan sumber-sumber belajar dan media pembelajaran. Banyak faktor yang diduga dapat mempengaruhi motivasi siswa untuk mengembangkan keterampilan berbicara bahasa Inggris di SMA Negeri 2 Kota Jambi, antara lain ialah: memperbaiki strategi pembelajaran, motivasi belajar siswa, kemampuan guru dalam mendesain pembelajaran berbicara bahasa Inggris, lingkungan dan iklim belajar serta media pembelajaran yang spesifik. Karena, Sesungguhnya media pembelajaran akan memberikan kemudahan bagi siswa untuk menyerap materi keterampilan berbicara bahasa Inggris yang disampaikan guru. Siswa lebih termotivasi apabila pelajaran diberikan dengan membawa siswa ke dalam dunia realitas yang konkrit. Sesuai dengan kematangan siswa SMA kelas XI, penggunaan media audiovisual sangat bermanfaat dalam membantu siswa dalam proses belajar mengajar, lebih baik lagi jika siswa dilibatkan dalam penggunaan dan pemanfaatan media yang ada di sekolah.

Berdasarkan gambaran di atas, maka banyak faktor-faktor yang mempengaruhi siswa untuk termotivasi sehingga senang belajar keterampilan berbicara bahasa Inggris . adapun faktor- faktor tersebut berasal dari dalam diri dan dari luar diri siswa tersebut. Dari dalam diri siswa ialah seperti: faktor biologis yang meliputi usia, kematangan berpikir, kesehatan dan lain-lain. Sementara faktor luar diri siswa adalah faktor keluarga yang terdiri dari: suasana 
rumah tangga, keadaan ekonomi orang tua, latar belakang kebudayaan yang sama dan berbeda. Berkaitan dengan faktor internal di dalam penyebab kesulitan belajar adalah motivasi yang merupakan suatu tindakan atau proses yang memberikan alasan kepada seseorang untuk melakukan sesuatu. Motivasi dalam belajar sangatlah penting untuk mencapai hasil belajar yang baik dan tuntas. Dalam rangka pembelajaran bahasa asing atau bahasa kedua khususnya bahasa Inggris juga sangat erat kaitannya dengan motivasi belajar. Disamping itu, dalam bahasa Inggris keterampilan berbicara (speaking) motivasi belajar sangatlah penting untuk mendukung keberhasilan pembelajar untuk dapat berbicara dengan baik dan lancar. (Sari, 2018: 41-52).

Termasuk juga sebagai faktor luar yang lain adalah faktor sekolah yang meliputi: strategi pembelajaran yang disajikan oleh guru mata pelajaran (Agustiarsyahnur: 2007), metode mengajar keterampilan bahasa Inggris, kurikulum pendidikan bahasa Inggris yang sesuai dengan kekinian dengan sebutan hi-tech (Muh. Ansyar: 2007), relasi guru-siswa yang harmonis dengan sebutan high-touch (Prayitno: 2007), disiplin sekolah, media pembelajaran yang sesuai dengan bidang studi ajar untuk membawa siswa benar- benar aktif untuk melatih diri dalam keterampilan berbicara bahasa Inggris (Adri: 2007) dan lain sebagainya. Akhirnya, faktor masyarakat yang meliputi: apa kegiatan siswa yang dilakukannya di tengah-tengah masyarakat sekitar sekolah, siapa teman bergaul di rumah, dan lain-lain.

Faktor media pembelajaran video (audiovisual) dan motivasi belajar keterampilan berbicara bahasa Inggris diduga adalah paling kuat mempengaruhi keterampilan berbicaranya karena setiap kesulitan yang dihadapi siswa saat belajar maka terbantu dengan media yang ada sehingga kecil kemungkinan bagi siswa tidak termotivasi. Media yang dipergunakan dalam penelitian ini ialah media audiovisual yakni Video tentang bagaimana orang asing dan orang pribumi (guru, siswa, masyarakat, pegawai, buruh dan lain-lain) berbicara bahasa Inggris. Mereka ditunjukkan di layar LCD sehingga nampak dilihat secara keseluruhan kegiatan-kegiatan yang berhubungan dengan latihan berbicara bahasa Inggris.

Jadi, penggunaan media pembelajaran Video tersebut diharapkan dapat menimbulkan semangat dalam diri siswa untuk berlatih keterampilan berbicara bahasa Inggris sehingga produknya nampak di mata masyarakat sekolah adanya. Sementara pada motivasi belajar dibatasi pada indikatornya: a) ketertarikannya terhadap penyampaian guru bidang studi bahasa Inggris, b) tertarik pada bidang studi bahasa Inggris, c) memiliki antusias tinggi untuk berbicara bahasa Inggris, d) mengingat dan berlatih kembali tentang model percakapan yang nampak dalam tayangan lalu, e) ingin selalu bergabung dengan kelompok diskusi kecil untuk berlatih dan menguji coba percakapan bahasa Inggris, f) keinginan pribadi siswa sebagai identitas diri hendaknya diakui. Dengan demikian, motivasi siswa tersebut bangkit lebih tinggi sehingga dalam melakukan training English speaking skills aktif dan berperan serta dalam pembelajaran sehingga hasil yang akan diperoleh dapat meningkat baik. Demikian juga motivasi rendah akan beroleh hasil yang minim alias kurang diharapkan oleh pengguna.

\section{METODE PENELITIAN}

Variabel dalam penelitian terdiri dari variabel bebas yaitu media pembelajaran berupa penggunaan video terhadap motivasi siswa. Sementara variabel terikat pertama adalah motivasi siswa kelas XI SMA dalam mempelajari keterampilan berbicara bahasa Inggris sebagai bahasa asing kedua yang wajib dipelajari di sekolah-sekolah mulai dari tingkat SLTP sampai ke tingkat Perguruan Tinggi (PT). Adapun variabel ini berfungsi untuk mengelompokkan siswa menjadi dua kelompok yakni kelompok siswa yang bermotivasi tinggi dan rendah sementara variabel terikat adalah hasil proses belajar mengajar pelajaran bahasa Inggris dalam hal ini dengan sub topik keterampilan berbicara bahasa Inggris.

Jenis penelitian ini quasi-experimental yang menggunakan dua kelas yakni kelas eksperimen dan kelas kontrol. Kelas eksperimen diberikan perlakuan dengan menggunakan media pembelajaran berupa video dalam PBM terhadap motivasi belajar dan keterampilan berbicara (speaking skills) siswa. Sementara pada kelas kontrol tidak diberikan 
perlakuan seperti pada kelas eksperimen namun kedua kelas tersebut diberikan materi yang sama. Penelitian dilaksanakan di SMA Negeri 2 Kota Jambi sejak bulan Agustus sampai dengan bulan Oktober 2020.

Penelitian eksperimen mencoba untuk meneliti ada tidaknya hubungan sebab akibat dengan membandingkan satu atau lebih kelompok eksperimen yang diberikan perlakuan khusus yakni dengan menggunakan media video pembelajaran, dalam penyajian mata pelajaran bahasa Inggris pada sub topik keterampilan berbicara (speaking skills) dengan kelompok lain yang tidak diberikan perlakuan khusus seperti yang di atas akan tetapi diperlakukan dengan metode konvensional.

Adapun pengumpulan data, peneliti melakukan tes keterampilan berbicara bahasa Inggris untuk mendapatkan gambaran hasil belajar siswa dalam bidang berbicara (speaking skills) dengan menggunakan media video pembelajaran dan yang tidak menggunakan media (kelas kontrol). Tes disusun dengan kompetensi dasar dan pokok bahasan yang dieksperimenkan. Kompetensi dasar yang diujikan adalah kemampuan siswa dalam percakapan bahasa Inggris.

Adapun indikator yang harus dicapai siswa adalah: menggunakan kosa kata, ketepatan ucapan bahasa Inggris, menjelaskan dan menjawab pertanyaan yang dipertanyakan oleh lawan bicara, menggunakan struktur yang benar, dan lain-lain. Selanjutnya, instrumen penelitian ini menggunakan tes lisan keterampilan berbicara bahasa Inggris yang menggunakan media video instrumen tes hasil disusun berdasarkan Tujuan Instruksional Khusus dari materi yang dieksperimenkan. Sementara untuk motivasi siswa digunakan angket yang disusun dalam bentuk kisi-kisi berdasarkan indikator- indikator kemudian dituangkan dalam bentuk pernyataan. Angket diberikan skor melalui skala Likert.

\section{HASIL DAN PEMBAHASAN}

Deskripsi data penelitian ini adalah meliputi variabel motivasi belajar siswa secara keseluruhan yang mengungkapkan informasi tentang skor total, skor tertinggi, skor terendah, rerata, standar deviasi, modus dan medium. Adapun profil data diatas dapat digambarkan dalam data dibawah ini sebagai berikut:

Tabel 1. Deskripsi Data Motivasi Belajar Keseluruhan

\begin{tabular}{|c|c|c|c|c|c|c|c|}
\hline \multirow[t]{2}{*}{ No } & \multirow[t]{2}{*}{ Statistik } & \multirow{2}{*}{$\begin{array}{c}\text { Motivasi } \\
\text { Belajar Kel. } \\
\text { Eksperimen }\end{array}$} & \multirow{2}{*}{$\begin{array}{c}\text { Motivasi } \\
\text { Belajar } \\
\text { Kel. } \\
\text { Kontrol }\end{array}$} & \multicolumn{2}{|c|}{$\begin{array}{l}\text { Motivasi Belajar } \\
\text { Kel. Eksperimen }\end{array}$} & \multicolumn{2}{|c|}{$\begin{array}{c}\text { Motivasi Belajar } \\
\text { Kel. Kontrol }\end{array}$} \\
\hline & & & & Tinggi & Rendah & Tinggi & Rendah \\
\hline 1 & Skor Total & 5585 & 5106 & 1674 & 1451,5 & 1563,5 & 1290 \\
\hline 2 & Skor & 194 & 190 & 194 & 169 & 190 & 151 \\
\hline 3 & Ter.Tgg & 150 & 136 & 180 & 150 & 166 & 36 \\
\hline 4 & Skor Trndh & 174,53 & 161,25 & 186 & 161,28 & 173,72 & 143,33 \\
\hline 5 & Rerata & 10,03 & 11,67 & 3,97 & 5,69 & 6,18 & 4,85 \\
\hline 6 & Stndr Dvs & 173,23 & 161,9 & 186,5 & 159,5 & 175,5 & 143,7 \\
\hline 7 & Modus & 174,25 & 160,25 & 160,83 & 160,83 & 176,33 & 144 \\
\hline & Media & & & & & & \\
\hline
\end{tabular}

Data deskripsi motivasi kelompok eksperimen (A1) meliputi: mean sd 174,53; skor maksimum ideal $=200$; standar deviasi $=10,03$; variansi $=100,52$; modus $=173,23$; dan median $=174,25$. Data deskripsi motivasi kelompok kontrol (A2) meliputi: mean sd 161,25; skor maksimum ideal $=200$; standar deviasi $=11,67$; variansi $=136,11 ;$ modus $=161,9$; dan median $=160,25$. Deskripsi data kelompok siswa yang memiliki motivasi tinggi yang diajarkan dengan media audiovisual (A1B1) meliputi: mean $=186$; skor maksimum ideal $=$ 200; standar deviasi sd 3,97; variansi $=15,75$; modus $=186,5$ dan median $=186$. Deskripsi data kelompok siswa yang memiliki motivasi rendah yang diajarkan dengan media 
audiovisual $($ A1B2) meliputi: mean $=161$ skor maksimum ideal $=200 ;$ standar deviasi $=5,69$; variansi $=32,41 ;$ modus $=159,5$ dan median $=160,83$. Deskripsi data kelompok siswa yang memiliki motivasi belajar tinggi yang diajarkan tanpa media audiovisual (A2B1)) meliputi: mean $=173,72$ skor maksimum ideal $=200$; standar deviasi $=61,8$; variansi $=38,16$; modus sd 175,5 dan median $=176,33$. Deskripsi data kelompok siswa yang memiliki motivasi belajar rendah yang diajarkan dengan tanpa media audiovisual (A2B2) meliputi: mean $=46,43$ skor maksimum ideal $=100$; standar deviasi $=8,76$; variansi $=76,68$; modus $=46,38$ dan median $=$ 46,38 .

Terdapat pengaruh media pembelajaran video terhadap keterampilan berbicara (speaking skills) siswa kelas XI SMA Negeri 2 Kota Jambi. Hal ini ditunjukkan berdasarkan hasil perhitungan uji hipótesis dengan nilai $\mathrm{t}=54,077$ dengan Sig. $0.000<0.05$ maka Hi diterima

\section{Pembahasan}

Dari hasil perhitungan dapat diperoleh hasil selisih rerata lebih besar dari nol, maka bisa disimpulkan bahwa terdapat interaksi antara penggunaan media audiovisual dalam proses pembelajaran bahasa Inggris pada sub topik keterampilan berbicara bahasa Inggris dan motivasi belajar siswa khususnya pada keterampilan berbicara (speaking skill). Baik kelompok siswa yang memiliki motivasi tinggi dan rendah apabila diajarkan dengan alat bantu belajar audio maka hasil keterampilan berbicara mereka akan menjadi lebih.

Media pembelajaran sebagai alat bantu dalam pembelajaran berfungsi sebagai penghantar materi pembelajaran kepada siswa. Hal ini jelas, bahwa dengan menggunakan media audiovisual maka materi pembelajaran cepat sampai kepada siswa dan dapat dipahaminya dengan baik. Media dalam pembelajaran, khususnya audiovisual adalah suatu kenyataan yang tidak dapat dipungkiri, karena gurulah yang menghendakinya dalam rangka membantu tugas guru untuk menyampaikan pesan-pesan dari bahan pelajaran yang diberikan guru kepada siswa. Guru menyadari bahwa tanpa bantuan media dalam PBM maka akan sulit bagi siswa melakukan keterampilan berbicara bahasa Inggris dengan cepat.

Sesuai dengan hasil penelitian yang dilakukan oleh Anggraeni (2019) tentang Pengaruh Media Pembelajaran Video Smart Hafiz Terhadap Keterampilan Bicara Anak. Jurnal Pelita PAUD. Hasil penelitian menunjukkan bahwa bantuan media pembelajaran video ternyata sangat efektif dalam meningkatkan keterampilan bicara anak. Dalam usaha memanfaatkan media sebagai alat Bantu Edgar Dale (dalam Sadiman, 1996) mengklasifikasikan pengalaman menurut tingkat dari yang paling konkrit sampai kepada yang abstrak yakni pengalaman langsung, observasi, partisipasi, demonstrasi, wisata, TV, film, radio, visual, simbol visual dan verbal. Dalam penggunaan media audiovisual dalam pembelajaran di samping meningkatkan motivasi belajar siswa dalam pembelajaran juga bermanfaat dalam meningkatkan prestasi dan hasil belajar tentang keterampilan berbicara bahasa Inggris sehingga dapat digunakan secara efektif mungkin dalam meningkatkan keterampilan berbicara bahasa Inggris.

Berdasarkan gambaran di atas, penelitian ini masih memperlihatkan keterbatasanketerbatasan seperti: penelitian ini hanya dilakukan pada siswa kelas XI SMA Negeri 2 Kota Jambi sehingga belum dapat dilakukan generalisasi kepada kelas lain yang paralel karena sampel penelitian belum mewakili keseluruhan karakteristik dari populasi; hasil penelitian yang dilakukan ini hanya dilihat dari dua sisi saja yakni: 1) pengaruh penggunaan media pembelajaran video dan 2) motivasi siswa terhadap proses pembelajaran keterampilan berbicara bahasa Inggris. Sementara hal-hal lain yang dianggap dominan untuk mempengaruhi proses pembelajaran keterampilan berbicara bahasa Inggris; walaupun instrumen penelitian telah memiliki validitas dan reliabilitas yang tinggi, namun instrument tersebut baru mengukur hasil belajar siswa tentang keterampilan berbicara bahasa Inggris dan belum dapat mengukur hasil belajar bahasa Inggris secara keseluruhan. 


\section{KESIMPULAN}

Berdasarkan hasil temuan di lapangan maka dapat disimpulkan bahwa: (1) Penggunaan media pembelajaran video dapat meningkatkan motivasi belajar siswa dalam pembelajaran sehingga siswa terlibat langsung secara aktif, kreatif, efektif dan menyenangkan ( $f$ hitung 5,050 dan $p<0,050$ ). Hasil penelitian ini juga menunjukkan terdapat interaksi antara penggunaan media pembelajaran video dan motivasi belajar terhadap hasil belajar siswa.

(2) terdapat pengaruh media pembelajaran video terhadap keterampilan berbicara (speaking skills) siswa kelas XI SMA Negeri 2 Kota Jambi. Hal ini ditunjukkan berdasarkan hasil perhitungan uji hipótesis dengan nilai $\mathrm{t}=54,077$ dengan Sig. $0.000<0.05$ maka Hi diterima.

\section{DAFTAR PUSTAKA}

Agustiarsyahnur. 2007. Seminar Manajemen Pendidikan. Pascasarjana UNP: Padang.

Anggraeni, D., \& Gustiana, E. (2019). Pengaruh Media Pembelajaran Video Smart Hafiz Terhadap Keterampilan Bicara Anak. Jurnal Pelita PAUD. 4(1). 139-149.

Daryanto. (2015). Peranan Media dalam Pembelajaran. Jakarta. Bumi Aksara

Falahudin, I. (2014). Pemanfaatan media dalam pembelajaran. Jurnal Lingkar Widyaiswara. 1(4). 104-117.

Fatmawati, P. Y. (2017). Pengaruh Metode Bermain Peran Dengan Video Dan Motivasi Belajar Terhadap Keterampilan Berbicara Bahasa Inggris Kelas VI SDN 1 Rangkasbitung Timur. Jurnal Pendidikan Dasar Setiabudhi. 1(1). 9-17.

Gordon, T. (1997). Menjadi Guru Efektif. Jakarta: Gramedia Pustaka.

Latuheru. (2016). Media pembelajaran. Surabaya: Kartika

Muhammad Ansyar. (2007). Pendidikan Kurikulum Indonesia. Program Pascasarjana UNP: Padang.

Prayitno. 2007. Seminar Ilmu Kependidikan. Pascasarjana UNP: Padang.

Sardiman, A.M. (2016). Interaksi dan motivasi belajar mengajar. Jakarta: PT Raja Grafindo Persada.

Sari, I. (2018). Motivasi belajar mahasiswa program studi manajemen dalam penguasaan keterampilan berbicara (speaking) bahasa Inggris. JUMANT. 9(1). 41-52. 